\title{
The influence of the kallikrein-kinin system on the characteristics of insulin receptors in rat skeletal muscle during ischemia
}

\author{
P. Maćkowiak', Hanna Krauss², J. Koźlik², P. Sosnowski², \\ J. Paluszak ${ }^{2}$, Kinga Mikrut $^{2}$ and Teresa Torlińska ${ }^{2}$ \\ 'Department of Animal Physiology and Biochemistry, \\ Poznan' Agricultural University \\ Wotyńska 35, 60-637 Poznan, Poland \\ 2Department of Physiology, University School of Medical Sciences \\ Święcickiego 6, 60-781 Poznañ. Poland
}

(Received 20 October 1997; accepted 14 January 1998)

\begin{abstract}
To investigate the role of kinins in ischemia, bradykinin and kininase II inhibitor (captopril) were injected to rats with acute ischemia of the hind limb. Maximum specific binding (Bsp\%) of insulin to hind limb muscle membranes as well as the number of insulin receptors were investigated. In ischemic rats glucose turnover was disturbed and its increased concentration in blood together with lowered binding of insulin were observed. Bradykinin and captopril normalized the glucose level, increasing insulin binding to membranes. Simultaneously, they elevated the number of low-affinity insulin receptors in muscle membranes of ischemic rats. In the light of the obtained results bradykinin and captopril seem to improve disturbed carbohydrate metabolism by affecting the number of insulin binding sites in muscles.
\end{abstract}

KEY WORDS: ischemia, bradykinin, insulin receptors, rat

\section{INTRODUCTION}

Activation of the kallikrein-kinin system occurs in tissues when the balance between the need for oxygen and its supply is disturbed. This phenomenon can be observed both in heart and skeletal muscle tissues (Needleman et al., 1975; Dietze et 
al., 1984). Tissue acidosis stimulates the activity of kallikreins leading to enhanced release of kinins (Regoli et al., 1980; Dietze et al., 1982), which in turn directly or by stimulation of prostaglandin synthesis stabilize a pool of cellular high-energy compounds during both ischemia and reperfusion (Zhu et al., 1995). This protective action is performed by stimulating of key enzymes of glucose metabolism and by increasing the of oxygen supply due to a vasodilatative effect (Dietze et al., 1982; Kaley et al., 1985). The postulated mechanism of kinin action is enhancement of prostacyclin and nitric oxide synthesis (Zhu et al., 1995). It is also known that kinins can affect glucose and amino acids transport, probably by increasing sensitivity of tissues to insulin (Dietze et al., 1980). Particularly effective action of kinins is observed in insulin deficiency conditions. However, the mechanisms by which kinins improve metabolism have still not been elucidated. It can be presumed, that insulin interaction with its cellular receptors may be involved to some degree - if not deeply - in the action of kinins on metabolism and through this, their protective effect on energetic processes arises. The effects caused by insulin in target tissues do not depend only on the level of this hormone in the blood, its interaction with membrane receptors that, transmit signals to the intracellular space also plays a major role.

In the presented work we have analyzed the possible, up to now not investigated, influence of the kallikrein-kinin system on insulin receptors number and insulin binding to rat skeletal muscles during ischemia.

\section{MATERIAL AND METHODS}

\section{Animals}

Adult, healthy, male Wistar rats weighing about $130 \mathrm{~g}$ were used for experiment. The animals were housed in room conditions (temp. $18^{\circ} \mathrm{C}$, photoperiod $12: 12 \mathrm{~h}$ ) with free access to water and food (LSM standard laboratory diet). All investigations were carried out taking into consideration the ethical aspects of the experimental procedure and were approved by of the Medical Academy Ethical Committee.

The animals were divided into four groups, 8 rats in each: group I - rats with normal blood supply. One $\mathrm{h}$ before sampling animals were subcutaneously injected with $1 \mathrm{ml}$ of $0.9 \% \mathrm{NaCl}$,

group II - rats with acute $24 \mathrm{~h}$ ischemia of hind limb provoked by placing (under narcosis) a subcutaneous tourniquet on the thigh at the level of inguinal ligament. Like the control group, $1 \mathrm{~h}$ before sampling the animals received $1 \mathrm{ml}$ of $0.9 \%$ $\mathrm{NaCl}$ subcutaneously, 
group III - rats with acute $24 \mathrm{~h}$ ischemia. One $\mathrm{h}$ before sampling the animals were injected with bradykinin (Serva $-0.32 \mathrm{mg} / \mathrm{kg} \mathrm{BW}$ ) dissolved in $1 \mathrm{ml}$ of $0.9 \% \mathrm{NaCl}$, group IV - rats with acute $24 \mathrm{~h}$ ischemia. One $\mathrm{h}$ before sampling the animals were injected with kininase II inhibitor captopril (Sigma $-3 \mathrm{mg} / \mathrm{kg} \mathrm{BW}$ ) dissolved in $1 \mathrm{ml}$ of $0.9 \% \mathrm{NaCl}$.

\section{Tissue sampling}

One hour after injection, the animals were anaesthetized by intraperitoneal $35 \mathrm{mg} / \mathrm{BW}$ Inactin (Byk-Gulden). Blood samples were taken by a right ventricle puncture. The obtained serum was used to determine glucose concentration (by the glucose oxidase method). Muscle samples taken from the thighs of each rat were immediately frozen in liquid nitrogen.

\section{Determination of insulin receptors and mathematical analysis}

Muscle tissue membranes were prepared according to the method of Havrankova et al. (1978). Incubation conditions were the same as described previously (Nowak et al., 1993). As ligands both, unlabelled pork insulin (Novo Industri, Denmark) and the hormone labelled with 125 iodine (specific activity $8.0 \mathrm{GBq} / \mathrm{mg}$; OPiDI Świerk, Poland) were used. In order to investigate insulin binding, $80 \mathrm{pg}$ of ${ }^{125}$ I-labelled hormone and varying amounts of unlabelled insulin were incubated with muscle plasma membranes. The conditions of the reaction were chosen on the basis of our own experience and literature data (Muggeo et al., 1979; Smith et al., 1986; Scapin and Incerpi, 1992), which indicate that incubation for $18 \mathrm{~h}$ at $+4^{\circ} \mathrm{C}$ is optimal to obtain both steady state and the highest specific binding. The nonspecific binding of ${ }^{125} \mathrm{I}$-insulin was determined at $10 \mu \mathrm{M}$ concentration of unlabelled insulin and substracted from the total binding of ${ }^{125}$ I-insulin at each concentration of unlabelled hormone to obtain the specific binding. The nonspecific binding of ${ }^{125} \mathrm{I}$-insulin was less than 5\%. Maximum binding capacities of two classes of receptors and association rate constants $\left(\mathrm{K}_{\mathrm{a}}\right)$ were determined by Scatchard's method (1949) using the LIGAND-PC v.3.1 computer program (Munson and Rodbard, 1980). The maximum binding capacity for each class of receptors was calculated per milligram of membrane proteins determined according to the method of Lowry et all. (1951).

Results were expressed as means \pm SEM. The results were interpreted statistically according to one-way analysis of variance. Significance of differences between groups was calculated using a multiple range test. For $\mathrm{P}<0.05$ differences were considered statistically significant. 


\section{RESULTS}

Figure 1 presents Scatchard's plots which reflect the dynamics of insulin binding to muscle membrane receptors. The characteristic curvilinearity observed in all cases suggests lack of homogenity of insulin receptors in muscle membranes in all of the investigated groups of animals. This characteristic shape of the curves is interpreted as an indication of the presence of two pools of insulin receptors in muscle membranes: high affinity insulin receptors (HAIR) and low affinity insulin receptors (LAIR). According to this interpretation, the generally accepted two-sites model for insulin receptor assay was used.

During ischemia maximum specific binding of ${ }^{125} \mathrm{I}$-insulin (Bsp\%) was slightly reduced (Table 1). In the control group Bsp\% equaled $4.0 \pm 0.5 \%$, whereas acute ischemia lowered this value to $3.2 \pm 0.6 \%$. Simultaneously, quantitative changes of insulin receptors were noticed. In the ischemia group the number of high affinity
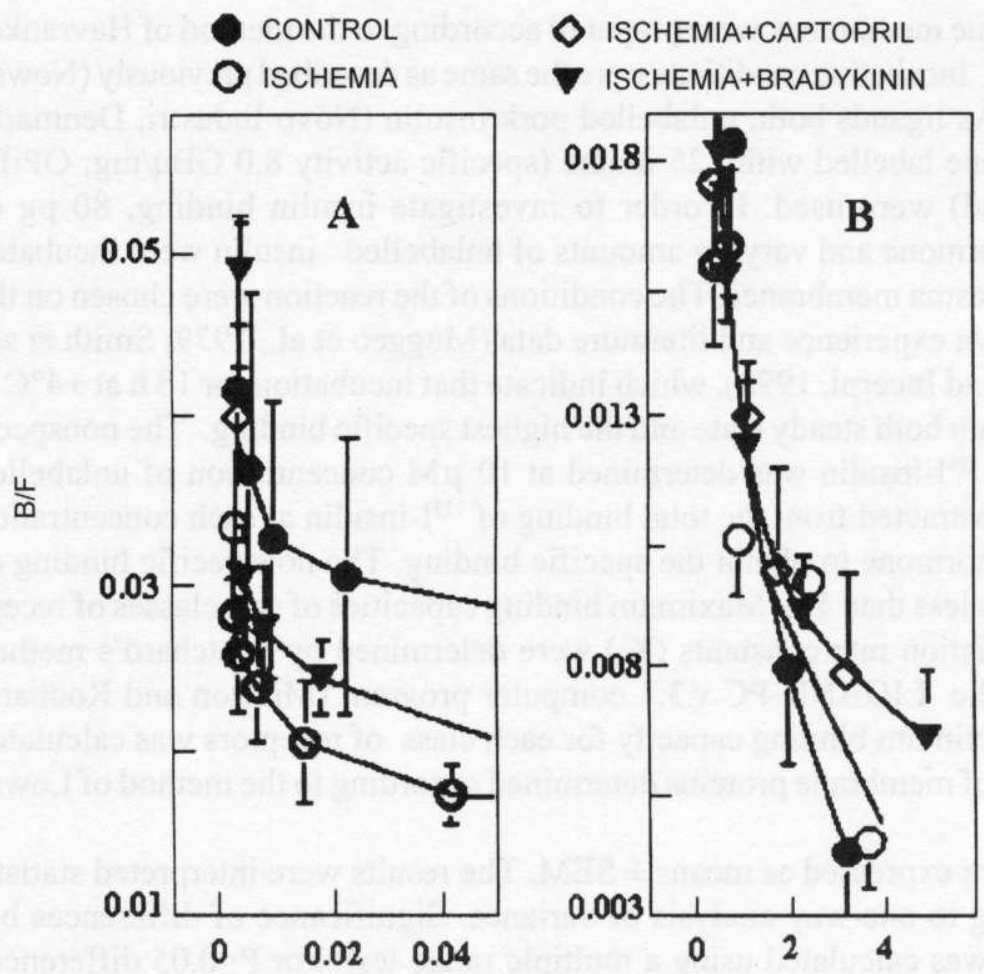

BOUND INSULIN, nmol/l

Figure 1. Scatchard plots of ${ }^{125}$ I-insulin binding to muscle plasma membranes for HAIR (A) and LAIR (B). B/F - bound to free insulin ratio. Results expressed as means and SEM for 8 animals 
TABLE 1

The effect of bradykinin or captopril in acute ischemia on glucose concentration in blood serum and insulin receptors content as well as insulin binding to muscle membranes $(n=8, \pm$ SEM)

\begin{tabular}{|c|c|c|c|c|}
\hline & \multirow{3}{*}{ Control } & \multirow{3}{*}{ Ischemia } & \multicolumn{2}{|c|}{ Ischemia } \\
\hline & & & + & + \\
\hline & & & bradykinin & captoprii \\
\hline Specific binding, $\%$ & $4.0 \pm 0.5^{\mathrm{ac}}$ & $3.2 \pm 0.6^{\mathrm{b}}$ & $4.7 \pm 0.6^{\mathrm{c}}$ & $3.8 \pm 0.6$ \\
\hline $\mathrm{HAIR}, \mathrm{fmol} / \mathrm{mg}$ protein & $29.5 \pm 3.5^{\mathrm{ac}}$ & $12.2 \pm 5.5^{b}$ & $32.1 \pm 5.9^{c}$ & $13.5 \pm 4.5$ \\
\hline $\mathrm{Ka}$ for HAIR, $1 / \mathrm{nmol}$ & $5.2 \pm 4.1$ & $10.1 \pm 7.8$ & $35.4 \pm 18.9$ & $36.8 \pm 22.7$ \\
\hline LAIR, $\mathrm{pmol} / \mathrm{mg}$ protein & $3.3 \pm 0.7^{\mathrm{a}}$ & $8.4 \pm 2.3^{\mathrm{b}}$ & $36.4 \pm 6.2^{c}$ & $19.5 \pm 3.3$ \\
\hline $\mathrm{Ka}$ for LAIR, $1 /$ umol & $9.2 \pm 4.5$ & $8.4 \pm 3.9$ & $3.7 \pm 2.8$ & $2.8 \pm 3.1$ \\
\hline Glucose, $\mathrm{mmol} / \mathrm{l}$ & $4.9 \pm 0.1^{3 \mathrm{c}}$ & $5.7 \pm 0.1^{\mathrm{b}}$ & $5.0 \pm 0.1^{c}$ & $5.1 \pm 0.1^{c}$ \\
\hline
\end{tabular}

$\mathrm{a}, \mathrm{b}, \mathrm{c}-\mathrm{P}<0.05$

insulin receptors (HAIR) decreased from $29.5 \pm 3.5 \mathrm{fmol}$ of binding sites per $1 \mathrm{mg}$ of membrane protein was reduced to $12.2 \pm 5.3 \mathrm{fmol} / \mathrm{mg}$. On the other hand, the number of low affinity insulin receptors (LAIR) increased from $3.3 \pm 0.7$ to $8.4 \pm 2.3 \mathrm{pmol} / \mathrm{mg}$. All of these changes were significant.

Administration of bradykinin to ischemic rats recovered or even improved the maximum specific binding of insulin with skeletal muscle membranes $(4.7 \pm 0.6 \%)$. This change of insulin binding is significant in comparison with muscles of ischemic rats. Also, after bradykinin injection, the number of binding sites increaseds. The number of HAIR returned to the control value $(32.1 \pm 5.9 \mathrm{fmol} / \mathrm{mg})$ whereas the number of LAIR was highly elevated. Simultaneously, glucose concentration, which was high in ischemic animals, decreased after bradykinin injection to a level close to control values.

Injection of captopril also caused an increase of maximum specific binding of insulin to muscle membranes $(3.8 \pm 0.6 \%)$ in comparison with the ischemic group. This increase was not as high as observed for bradykinin but was accompanied by significant enlargement of the low affinity receptor pool $(19.5 \pm 3.3 \mathrm{pmol} / \mathrm{mg})$. Simultaneously, level of glucose in blood decreased significantly in comparison with ischemic rats.

\section{DISCUSSION}

The molecular mechanisms of kinin action have not been elucidated conclusively. It is not clear if these compounds influence only transmembrane glucose transport, or whether they also change tissue sensitivity to insulin, altering binding of this hormone to its receptors. The number of insulin receptors, commonly present on cell membrane surfaces, varies significantly, depending on the type of cell and 
physiological condition of the organism. It is influenced by many physiological and pathological factors (Gammeltoft, 1984). Muscles contain, like other tissues, two classes of insulin receptors. Both classes of binding sites that differ in affinity to insulin, can be responsible for reaction to this hormone. As a rule, muscles are treated as an insulin target tissue (Gammeltoft, 1984). However, in contrast with the liver, the insulin concentration entering muscles is many times lower. Thus, a class of high affinity insulin receptors, receptors which respond to physiological concentrations of insulin in blood, seem to play a main role. Furthermore, the exceptionally high number of LAIR noticed in the muscles is hard to explain. However, we have noticed elevation of the quantity of LAIR before. Similar results were obtained investigating insulin receptors in rat muscles during hypothermia. Elevation of the LAIR content in hypothermia improves insulin binding to muscles (Torlinska et al., 1996) and seems to be a mechanism which is responsible for maintaining both the physiological concentration of glucose in blood and proper carbohydrate utilization, including glycogen storage. A similar situation was observed in the present experiments. Ischemia, which disturbs the natural functioning of muscles, influences glucose turnover in the whole body and leads to enhancement of the glucose level in blood. A slight increase in LAIR during acute ischemia is probably a defense reaction against the pathological state. Injection of bradykinin improves insulin binding to muscle membranes probably by the observed significant elevation of the number of low affinity receptors. This focus, in turn, is probably responsible for improvement of carbohydrate turnover and restoring the glucose concentration in blood to the control values. However, the mechanism by which bradykinin influences the number of insulin receptors is hard to explain. It is not known if this kinin stimulates the synthesis of new receptor particles, or, by changing the conformation and fluidity of membranes, enables insulin binding to unoccupied receptors present in the membrane. Both ways, discussed in papers, are a possible mechanism of action of many different biologically active substances (Leal et al., 1992; Sesti et al. 1992). On the other hand, authors postulate some cross-link between insulin and bradykinin receptors at the stage of postreceptors intracellular events. Signals from the insulin receptor probably modify signaling from the bradykinin receptor to tyrosine phosphorylation of different cellular proteins. Protein kinase $\mathrm{C}$ isoforms activated by bradykinin receptors can also exert a regulatory effects on insulin receptors (Haring et al., 1996).

The decrease in the blood glucose level noticed in our study is in good agreement with the results obtained by other authors. Bradykinin not only increases insulin secretion in vitro and may play a similar physiological role in vivo (Yang and $\mathrm{Hsu}$, 1995; Saito et al., 1996), but also mimics insulin action on translocation of glucose transporters (GLUT1 and GLUT4) in muscles (Rett et al., 1996). As the effect of bradykinin action, increased glucose uptake and increased sensitivity of tissues to insulin is observed (Kohlman et al,, 1995). Kininase II inhibitors also seem to 
influence carbohydrate metabolism. Trandolapril improves the sensitivity of glycogen synthesis to insulin in the soleus muscle (Leighton et al., 1996). Captopril can improve the glucose transport system in skeletal muscles and this improvement, according to Henriksen and Jacob (1995), involves bradykinin metabolism (Henriksen et al., 1996). Bradykinin, in turn, according to some recent concepts, can influence tyrosine kinase and tyrosine phosphatase activity leading to phosphorylation of MAP kinases and probably activating the Ras GTP/Raf pathway. To these postulated ways of bradykinin action we add one more - bradykinin enhances the number of insulin receptors. Captopril shows similar properties and seems to act in the same way. This is in a good agreement with results obtained by Rett et al. (1996) who revealed a higher rate of elimination and utilization of glucose after administration of captopril. Similar results were also obtained by Koźlik (1996) after application of kallikrein-kinin system modifiers in streptozotocin-induced diabetes.

In conclusion, we find state that bradykinin as well as captopril can improve carbohydrate metabolism disturbed in ischemia, and one of the possible ways of action is augumentation of insulin receptor number, which, as a consequence, improve hormone binding to muscle membranes.

\section{CONCLUSIONS}

Ischemia lowers specific binding of insulin to muscle membrane receptors changing the number of both high- and low-affinity binding sites, resulting in an elevation of the blood glucose level.

Bradykinin and captopril improve carbohydrate metabolism in ischemic animals elevating the number of low-affinity insulin receptors and increasing insulin binding to muscles.

\section{REFERENCES}

Dietze G., 1982. New aspects of the blood flow-augmentin and insulin-like activity of muscle exercise: possible involvement of the kallikrein-kinin-prostaglandin system. Klin. Wochenschr. $60,429-444$

Dietze G., Wicklmayr M., Boettger J., Schifmann R., Geiger R., Fritz H., Mehner H., 1980. The kallikrein-kinin system and muscle metabolism: biochemical aspects. Agents and Actions 10 , 335-338

Dietze G., Maerker E., Lodri C., Schifmann R., Wicklmayr M., Geiger R., Fink E., Boettger I., Fritz H., Mehner H., 1984. Possible involvement of kinins in muscle energy metabolism. Adv. Exp. Med. Biol. 167, 63-71

Gammeltoft S., 1984. Insulin receptors: binding kinetics and structure-function relationship of insulin. Physiol. Rev. 64, 1321-1377 
Haring H.U., Tippmer S., Kellerer M., Mosthaf L., Kroder G., Bossenmaier B., Berti L., 1996. Modulation of insulin receptor signaling. Potential mechanisms of a cross talk between bradykinin and the insulin receptor. Diabetes 45, Suppl.1, 115-119

Havrankova J., Roth J., Brownstain M.J., 1978. Insulin receptors are widely distributed in the central nervous system of the rat. Nature $272,827-829$

Henriksen E.J., Jacob S., 1995. Effects of captopril on glucose transport activity in skeletal muscle of obese Zucker rats. Metabolism 44, 267-272

Henriksen E.J., Jacob S., Augustin H.J., Dietze G.J., 1996. Glucose transport activity in insulinresistant rat muscle. Effects of angiotensin-converting enzyme inhibitors and bradykinin antagonism. Diabetes 45, Suppl.1, 25-28

Kaley G., Hinze T.H., Panzenbeck M., Messina E.J., 1985. Role of prostaglandin in microcirculatory function. Adv. Prostagl. Thromb. Leukotr. Res. 13, 27-35

Kohlman O. Jr., Neves F. de A., Ginoza M., Tavares A., Cerazetti M.L, Zanella M.T., Ribeiro A.B., Gavras I., Gavras H., 1995. Role of bradykinin in insulin sensitivity and blood pressure regulation during hyperinsulinemia. Hypertension 25, 1003-1007

Koźlik J., 1995. The influence of kallikrein-kinin system modifiers on oxidizing stress in streptozotocon-induced diabetic rats (in Polish). Poznań Medical Academy Scientific Publishers

Leal M.A, Cabanas C., Rius C., Aller P., Calle C., 1992. Modulation by dexamethasone of insulin binding and receptor mRNA levels in U-937 human promonocytic cells. Biochimie 74, 545-549

Leighton B., Sanderson A.L., Young M.E., Radda G.K., Boehm E.A., Clark J.F., 1996. Effect of treatment of spontaneously hypertensive rats with angiotensin-converting enzyme inhibitor trandolapril and the calcium antagonist verapamil on the sensitivity of glucose metabolism to insulin in rat soleus muscle in vitro. Diabetes 45, Suppl. 1, 120-124

Lowry O.H., Rosenbrough N.J., Farr A.L., Randall R.J., 1951. Protein measurement with the Folin phenol reagent. J. Biol. Chem. 193, 265-275

Muggeo M., Ginsberg B.H., Roth J., Neville D.M., De Meyts P., Kahn R., 1997. The insulin receptor in vertebrates is functionally more conserved during evolution than insulin itself. Endocrinology 104, 1393-1402

Munson P.J., Rodbard D., 1980. LIGAND: a versatile comuterized approach for characterization of ligand-binding systems. Anal. Biochem. 107, 220-239

Needleman P.S., Key S.L., Denny S.E., Isaksson P.L., Marschal G.R., 1975. Mechanisms and modyfication of bradykinin-induced coronary vasodilatation. Proc. natn. Acad. Sci. 72, 2060-2063

Nowak K.W, Maćkowiak P., Nogowski L., 1993. Comparative studies on fish and bird insulin receptors. Acta Biochim. pol. 40, 231-236

Regoli D., Barabe J., 1980. Pharmacology of bradykinin and related kinins. Pharmacol. Rev. 32, 1- 46

Rett K., Wicklmayr M., Dietze G.J., Haring H.U., 1996. Insulin-induced glucose transporter (GLUT1 and GLUT4) translocation in cardiac muscle tissue is mimicked by bradykinin. Diabetes 45 , Suppl. 1, 66-69

Saito Y., Kato M., Kubohara Y., Kobayashi I., Tatemoto K., 1996. Bradykinin increases intracellular free $\mathrm{Ca}^{2+}$ concentration and promotes insulin secretion in the clonal beta-cell line, HIT-T15. Biochem. Biophys. Res. Commun. 221, 577-580

Scapin S., Incerpi S., 1992. Annual variations in the binding of insulin to hepatic membranes of the . frog Rana esculenta. Gen. Comp. Endocr. 86, 128-137

Scatchard G., 1949. The attraction of proteins for small molecules and ions. Ann. N.Y. Acad. Sci. USA. $51,660-672$ 
Sesti G., Marini M.S., Briata P., Tullio A.N., Montemurro A., Borboni P., De Pirro R., Gherzi R., Lauro R., 1992. Androgens increase insulin receptor mRNA levels, insulin binding, and insulin responsiveness in HEp-2 larynx carcinoma cells. Mol. Cell. Endocr. 86, 111-118

Smith D.H., Palmquist D.L., Schanbacher F.L., 1986. Characterization of insulin binding to bovine liver and membrane microsomes. Comp. Bioch. Phys. 85A, 161-169

Torlińska T., Maćkowiak P., Nogowski L., Koźlik J., 1996. Effect of hypothermia on the insulin receptor interaction in skeletal muscle plasma membranes. J.Physiol. Pharmacol. 47, 311-317

Yang C., Hsu W.H., 1995. Stimulatory effect of bradykinin on insulin release from perfused rat pancreas. Amer. J. Physiol. 268, E1027-E1030

Zhu P., Zaugg C.E., Simper D., Hornstein P., Allegrini P.R., Busre P.T., 1995. Bradykinin improves postischaemic recovery in the rat heart: role of high energy phosphates, nitric oxide, and prostacyclin. Cardiovasc. Res. 29, 658-663

\section{STRESZCZENIE}

\section{Wpływ ukladu kalikreiny-kininy na charakterystykę receptora insuliny w mięśniach szkie- letowych szczura podczas niedokrwienia}

W celu przebadania roli kinin w niedokrwieniu, wstrzykiwano szczurom z ostrym niedokrwieniem bradykininę oraz kaptopril - inhibitor kininazy II. Badano specyficzne wiązanie insuliny (Bsp\%) do błon mięśni udowych jak również liczbę receptorów tego hormonu. U szczurów z niedokrwieniem wystąpiły zaburzenia metabolizmu glukozy objawiające się podniesionym jej stężeniem we krwi, czemu towarzyszyło zmniejszone wiązanie insuliny. Bradykinina $i$ kaptopril normalizowały stężenje glukozy zwiększając wiązanie insuliny z błonami. Jednocześnie zwiększały one w błonach mięśniowych szczurów z niedokrwieniem liczbę receptorów o niskim powinowactwie. W świetle uzyskanych wyników bradykinina i kaptopril wydają się usprawniać zaburzony metabolizm węglowodanowy wpływając na liczbę miejsc wiążących insulinę w mięśniach. 